\title{
STEAM Elementary School with the Concept of Creative Learning Space in Heidegger's View
}

\author{
Rudy Trisno ${ }^{1 *}$, Fermanto Lianto $^{1}$, Natasha Kurnia Tishani ${ }^{1}$ \\ ${ }^{1}$ Department of Architecture, Universitas Tarumanagara, Jakarta, Indonesia \\ *rudyt@ft.untar.ac.id
}

This research aims to find out that education significantly influences the way people live in the world; with today's education, humans and robots have become blurred. Therefore, it is necessary to change the curriculum and education, architecture which are the main problems Heidegger's views used as a reference in this study. The solution offered to apply the future curriculum, namely STEAM, to the education system and its architectural forms by creating creative spaces and creating architecture that exudes human existence in them with metaphorical architecture. In this study, the current incidence of COVID-19 is taken as the context of the times humans are in, so it is necessary to make a school design responsive to Covid-19. The method applied: 1) Applying the concept of 'being' in Heidegger's philosophy; 2) Creating a creative space; 3) Creating a strategy when the Covid-19 incident in Heidegger's philosophy of 'time'. Architects need to think about the people who feel the existence of buildings in terms of form and function. The findings; how to create creative spaces to help the learning process in schools so that children can be motivated by their creativity by referring to Heidegger's views on 'being and time'.

Keywords: Being and Time; Covid-19; Creative Space; Metaphor; STEAM Education 


\section{INTRODUCTION}

So far, the world has experienced very rapid technological developments, marked by the Industrial Revolution, which even now has entered the 5.0 industrial era. Humans must be able to compete with robots in their work because in the future, human labour may be replaced by robots, and eventually, human existence is replaced by technology. To prepare for the future, humans, especially the younger generation as the nation's successor, must change the education system to maintain their existence in the world.

However, current education is no longer relevant for the future, one of which is that Indonesia has lagged behind its education compared to developed countries around the world, according to the exceptional staff of the Indonesian president (Putra, 2020). The covid-19 incident exacerbated this; although teaching and learning activity can be carried out from home, according to the Indonesian education minister Nadiem Makarim, in his interview, he said that emotional bonds between teachers and students and between friends could not be obtained from interactions via computer screens (Corbuzer, 2020).

The education system in the future needs to be changed by honing the skills needed for the future. These skills are 4C (Creativity, Collaboration, Communication, and Critical Thinking); these skills are predicted to be skills that robots cannot replace and need to be applied in schools today (Zubaidah, 2018). STEAM (Science, Technology, Engineering, Art, and Mathematics) is a 21st-century education curriculum that supports 4C skills: science, technology, engineering, art, and mathematics.
Many studies discuss STEAM education, such as STEAM education problems (Kyung Jung \& Hong, 2020), to apply STEAM education.

Creativity as a soft skill in 4C and STEAM is very complex. Creativity has become a topic of discussion in many recent studies (Batey \& Furnham, 2010). Still, the definite results regarding this have not yet been fully disclosed (Garcês, Pocinho, de Jesus, \& Viseu, 2016) and have not been thoroughly discussed in detail. The research offered so far is only limited to the influence of the creative space itself, such as the influence of creative space in general (Garcês, Pocinho, de Jesus, \& Viseu, 2016), to the influence of creative space on certain spatial functions such as libraries (Lavranos, Manousaki, \& Kostagiolas, 2020), architect workspace (Kesseiba, 2017); to the schoolroom (Davies, et al., 2013). No one has ever discussed how to apply the architectural physical form in a school building project, especially the STEAM curriculum in elementary schools, emphasizing this skill.

It is also not spared from research that discusses design elements in primary schools such as; circulation of school buildings (Mustafa \& Rafieq, 2019); Technology that must be applied in schools (Birt \& Cowling, 2017); to air quality in schools (Yang, et al., 2015), as well as several studies on learning systems in schools such as: creating fun learning in schools (Wicaksono, 2020), to implementing project-based learning methods in schools (Tasci, 2015). For more details, it can be seen in Table 1 .

Table 1 : Prior Research Regarding Primary Schools, STEAM Education, and Creative Spaces.

\begin{tabular}{lll}
\hline \multicolumn{1}{c}{ Title } & \multicolumn{1}{c}{ Summary } \\
\hline $\begin{array}{l}\text { Assessment of Elementary School Buildings in Erbil City } \\
\text { Using Space Syntax Analysis and School Teachers }\end{array}$ & $\begin{array}{l}\text { Analyze three types of school plan typology (L, } \\
\text { U, and to determine primary schools' adequate } \\
\text { circulation and accessibility systems. }\end{array}$ \\
\hline Joyful Learning in Elementary School (Wicaksono, 2020) & $\begin{array}{l}\text { It was trying to propose learning with mobile } \\
\text { technology to create a fun learning in elementary } \\
\text { schools. }\end{array}$ \\
\hline $\begin{array}{l}\text { Project-Based Learning from Elementary School to } \\
\text { College, Tool: Architecture (Tasci, 2015) }\end{array}$ & $\begin{array}{l}\text { Discussing project-based learning affects } \\
\text { academic achievement, learning resilience, and } \\
\text { positive learning functionality. }\end{array}$ \\
\hline $\begin{array}{l}\text { Toward Future' Mixed Reality' Learning Spaces for } \\
\text { STEAM Education (Birt \& Cowling, 2017) }\end{array}$ & $\begin{array}{l}\text { Studying academic perspectives by conducting } \\
\text { case studies of mixed reality visualization } \\
\text { technology in spatial design, paramedical } \\
\text { science, and information technology STEAM } \\
\text { learning. }\end{array}$ \\
\hline $\begin{array}{l}\text { A Theoretical Need for Applying Flipped Learning to } \\
\text { STEAM Education (Kyung Jung \& Hong, 2020) }\end{array}$ & $\begin{array}{l}\text { Discusses STEAM education problems and } \\
\text { offers solutions in the flipped learning method to } \\
\text { achieve STEAM goals. }\end{array}$ \\
\hline
\end{tabular}


Implementing STEAM in The Early childhood Classroom This study focuses on the need for STEAM (DeJarnette, 2018) education at the early childhood level.

Developing Creative "Spaces" in Libraries for Creative Discusses how the library provides opportunities Tourism

(Lavranos, Manousaki, \& Kostagiolas, 2020) to create cultural participation and develop creativity in the tourism experience.

Introducing Creative Space: Architectural Design Studio for Architecture Students; Challenges and Aspirations (Kesseiba, 2017)

It aims to enhance architectural creativity, taking into account the psychology and environmental characteristics, to create an environment that can stimulate the creative thinking of architects,

The Impact of Creative Environment on The Creative It shows the significant influence of the creative Person, Process, and Product

(Garcês, Pocinho, de Jesus, \& Viseu, 2016) environment on creative processes and products.

Creative Learning Environments in Education - A Contains a systematic review of 210 pieces of Systematic Literature Review (Davies, et al., 2013) educational research, policy, and professional literature relating to creative environments for learning in schools.

Because of the explanation above, in this research, the author tries to enrich the research by providing an explanation and application of the stages of forming creative space design in elementary schools with the STEAM curriculum as a solution to the displacement of human existence by technology because today's education is still left behind, This research was based on Heidegger's view of being and time which discusses human existence itself.

The research aimed to address the gaps in practical knowledge and population in previous studies. Other than that, not forgetting to respond to the covid-19 incident, which also impacts education, the author discusses the covid-19 design strategy for primary school buildings. This research also aims to inspire other architects in creating educational buildings in the future, where it is hoped that this research can become an example for elementary schools that are still fixated on 19th-century elementary school designs and can be used as a reference for designing schools that are responsive to the Covid-19 incident.

\section{LOCATION AND DETERMINATION OF EDUCATION LEVEL}

According to the great staff of the president of the Republic of Indonesia, the leading cause of Indonesia's lagging education is the outdated Indonesian curriculum which only sticks to numbers and educational buildings which still adhere to the factory system in the 19th century. There needs to be a change in the two essential elements of education so that Indonesian education can also compete with the future (Figure 1).

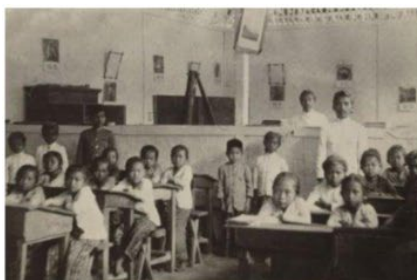

(a)

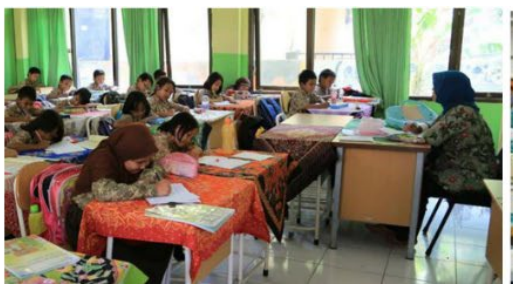

(b)

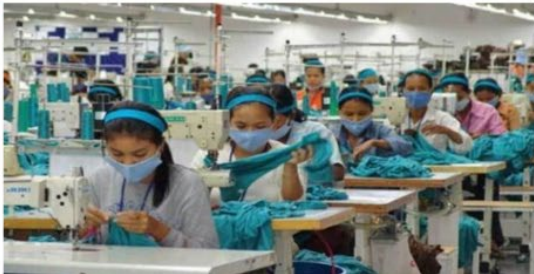

(c)

Figure 1 : Comparison of $19^{\text {th }}$-century Indonesian School to the Present Day with Factory Workspaces. Source: (a) IDN Times (2019) (b) Liputan 6 (2020) (c) Asia News (2016)

As one of the most developed cities in Indonesia, Jakarta is sadly still behind in its education. Therefore, this research takes Jakarta as the location for the research to take place. The determination of the level of education is also based on the teacher feasibility test results and the education ratio (Teacher: Student) based on the level of education. Primary school education was chosen as the level of education that had an urgency to make changes because it had the lowest teacher feasibility test results and a high education ratio. From the explanation above, this research is in the form of an elementary school building with the STEAM curriculum located in Kelapa Gading, North Jakarta, with a site that has educational zoning.

\section{THEORITICAL APPROACH}

In creating the architecture of an educational

41 Journal of Design and Built Environment, Vol 21(2) 39-58, August 2021 Trisno. et al. 
building, apart from understanding the education system in it, it is also necessary to pay attention to the people inside. Because in architecture, a design can never be separated from human existence (Trisno \& Lianto, 2021). The philosophy that is wanted to be taken to interpret human existence in this research is dasein, the German language for "being there", and is often translated into existence. Humans who are "being" need to be interpreted more deeply about how to interpret human existence in building architecture in the context of time. Heidegger defines dasein as creatures who understand what it feels like to be something, where dasein is said to be "being" when they bring out what is inside of them and take part in the world, instead of being isolated from the world (Tjahyadi, 2008; Iwuagwu, 2017).

According to Heidegger, existence can exist in his book Being and time because it is time (Heidegger, 2010). Thus, being and time are interrelated; existence is about the relationship between 'being' and time (Tjahyadi, 2008). The existence of children must be present in the architecture of the school building and begins when they start at the elementary school level. At this stage, the children begin to paint to express their thoughts and existence before finally writing. These paintings can be applied to architectural forms using a tool, namely the metaphorical architectural approach.

According to Anthony C. Antoniades (1992), metaphor is understanding something by seeing it as something else. He divides metaphors into three types: abstract metaphors derived from abstract values, ideas, concepts, traditions, culture, and others (Antoniades, 1992). This metaphor can be used as a tool to transfer the form of the existence of trim to the architecture of elementary school buildings while still paying attention to the function of the building itself so that form and function continue to run in harmony (Trisno \& Lianto, 2019).

Meanwhile, to better understand human existence, looking at current education, humans cannot develop the skills within them and cannot take part in the world, and as a result, humans cannot be said to be in the world. Therefore, there is a need for changes in the curriculum and educational architecture, which are the main problems in today's education, by implementing a future curriculum that allows children to maximize what is inside themselves with the STEAM curriculum that creates an architectural form. To make this happen, we need to dig deeper into this curriculum's understanding and learning methods. STEAM has a learning concept where science and technology subjects are implemented in engineering and arts based on mathematics. STEAM is a curriculum that integrates science, technology, art, and mathematics into one complete learning framework (Yakman, 2008).

The research has shown that STEAM positively impacts early childhood and elementary schools and has become a topic of discussion in international discussions as a curriculum suitable for the 21st-Century generation (Taylor, 2016). This implement STEAM in architecture, it is necessary to discuss the learning methods applied to the STEAM curriculum:

a) Learning methods in STEAM Education

STEAM itself has Project-Based Learning (PBL) learning method; this learning method applies contextual learning with world problems through complex activities where children are directly involved in creating a product through collaborative projects (Adriyawati, Utomo, Rahmawati, \& Mardiah, 2020).

Learning with the PBL method is carried out in collaboration between students, teachers, and the surrounding community. The PBL learning method allows children to use all their senses in learning, where according to research, STEAM can hone 4C skills (Ekawati \& Marhaeni, 2019). By knowing the learning method applied to STEAM, the next step is implementing it in school building architecture.

\section{b) STEAM education in architecture}

In accommodating STEAM learning, the learning space must accommodate the PBL learning method activities by creating certain facilities at the school. Creating an integrated and wellconnected STEAM school design is a key to create STEAM Architecture so that STEAM architecture and education can work together to accommodate learning activities that reach all education components (STEAMedu, 2015). In addition to understanding learning methods in a school, it is also necessary to know curriculum goals. This education system wants to achieve creativity in the STEAM curriculum itself especially with the (A) Arts element added to this education (Hau, Cuong, \& Tinh, 2020). Therefore, the architecture of educational buildings should also rethink how to inspire student creativity through architectural forms to realize the existence of children in the building by helping the process of student creativity.

Many studies have studied creative space as a space that can help someone's creative process. With space like it, it is hoped that humans can be motivated and channel their abilities to the 
maximum and take part in a world that exists. A creative space itself is defined as physical elements on various scales designed to support and facilitate the creative work process (Thoring, 2019).

The scale of this architectural physical form can be applied to start from just choosing colors to the shape of the building itself. Thoring (2019) suggested a tool in a pattern language to create a creative space to stimulate a person's creative process, consisting of 49 patterns applied to building projects in various forms. These patterns are chosen based on the typology of creative space that we want to create on the project, which consists of:

a) Space Type

- Personal space; Space used to concentrate fully while working; the characteristics of this space are serenity and minimal distraction.

- Collaboration space; The space used to collaborate in group work.

- Presentation space; This room is used for presentations or getting ideas and sharing knowledge.

- Making Space; Space is used in the process of experimenting with something.

- Intermission Space; The space that connects all space types is usually in a transition room for relaxing or a corridor.

b) Spatial Quality

- Knowledge process; To display knowledge in various forms, which allows the transfer of information.

- Indication of culture; Space requires certain habits in the form of a sign, written and unwritten regulations, and others.
- Process enabler; A space that provides a specific infrastructure that directs users to perform a behaviour.

- Social dimension; Supports social interaction and knowledge exchange.

- Source of stimulation; Space stimulates the human senses.

Heidegger's philosophy of being and time, which also discusses time, must discuss events that occur at this time so that this research becomes context with the present time. Therefore it is necessary to discuss the covid-19 events, which are currently rife, so that in addition to being comfortable, school is also safe. It is known that Covid-19 spreads through; 1) Airborne; 2) Physical contact, and 3) Respiratory droplets (WHO, 2020); with this fact, there are several things we can do as researchers to prevent this spread.

According to research, the cross-ventilation system that involves natural air can prevent airborne spread (Escombe, et al., 2007; Qian, et al., 2010), where the cross-ventilation system itself is a passive cooling system, with the primary source is natural air (Ohba \& Lun, 2010) which is very influential for buildings in tropical climates compared to cold climates (Levin, 2007). Apart from creating a cross-ventilation system, social distancing efforts can also be made, an effective effort to reduce transmission of diseases with high contamination levels (Caley, Philp, \& McCracken, 2008; Creator \& Corona, 2020). Meanwhile, according to the AIA (American Institute of Architects), the recommended social distancing distance is as far as 6' between study desks and 6' between children (Figure 2) (Dougherty, et al., 2020).

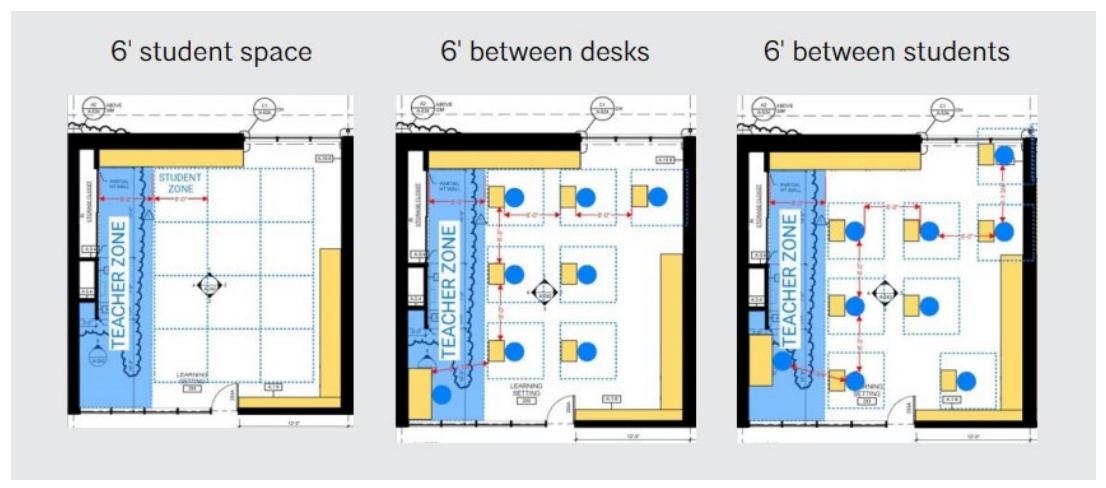

Figure 2 : Social Distancing in the Classroom.

Source: Reopening America: Strategies for Safer School (Dougherty, et al., 2020)

To further maximize the efforts to deal with

covid-19, a strategy should also be implemented 
by increasing the number of outdoor learning spaces, where according to AIA, outdoor spaces have a much lower transmission rate than indoor spaces indoor (Bobenhausen, Grant, Lau, Leung, \& Scanlon, 2020). It is also necessary to change the artificial air aeration from Merv- 8 to Merv-13 and provide UV light technology (Bobenhausen, Grant, Lau, Leung, \& Scanlon, 2020). According to several sources of small efforts, such as using touchless technology and placing sanitation equipment at several points, it is also essential to apply it to buildings.

\section{METHODOLOGY}

Of all the theoretical explanations that underlie the design of the elementary school architecture of the STEAM curriculum and regarding design strategies to overcome the Covid-19 incident, obtained a methodology that is the answer to the issues sublimated in the conclusions and findings.
The methodology used to be applied in several steps that can be used as a reference tool in designing, namely as follows: a) Applying the concept of creating the existence (Dasein) of children to mass compositions to embody the elements of 'being' in Heidegger's philosophy of being and time through an elementary school child; b) It is creating creative space by determining the type of creative space before determining the pattern of creative space to be used in research and c) Creating a design strategy that applied when the Covid-19 incident occurs to realize the element of 'time' in Heidegger's philosophy of being and time. This research's stages produce an architectural design of an elementary school building with a STEAM curriculum with a creative space concept while still anticipating the Covid-19 incident (Figure 3). This research's information and data were obtained through literature studies from all reliable sources, supporting the research process later.

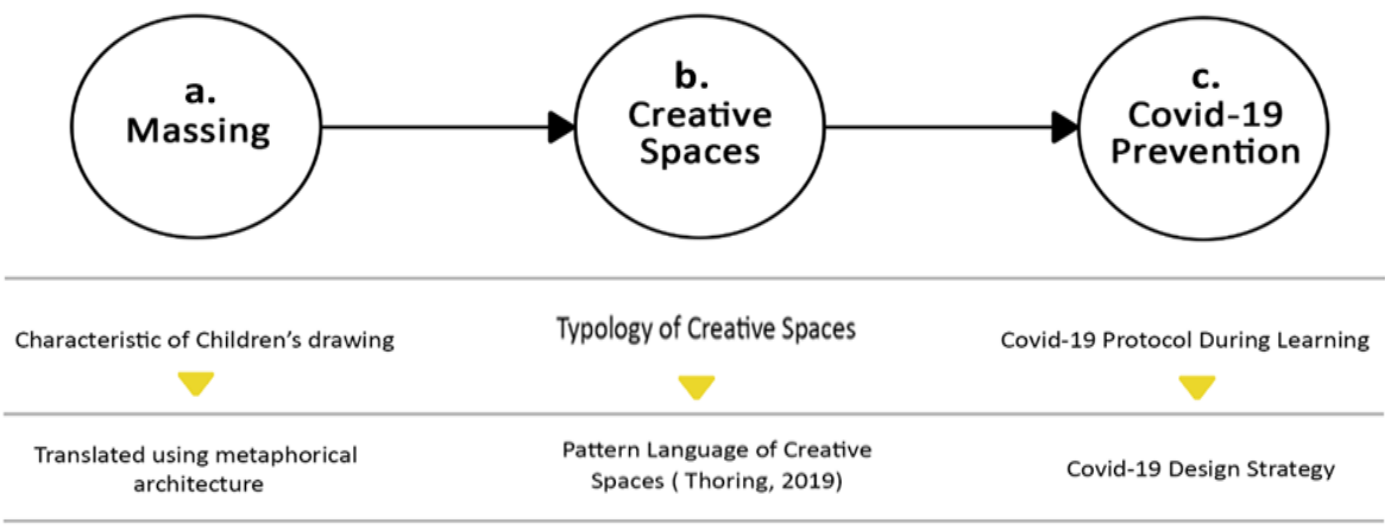

Figure 3 : Design Method Stages in the Diagram. Source: Authors, 2021

\section{RESULT AND DISCUSSION}

This section discusses each stage of the research method (Figure 3), starting from discussing the mass composition that takes the concept of dasein from Heidegger. The concept of dasein is sublimated by expressing the characteristics of children's paintings to be transformed into their architectural form using metaphor architecture. After that, creative space began to be created by first identifying the typology of creative space in the main room program, then determining which creative space pattern was appropriate, and finally, it could be directly applied to this research.

\subsection{Massing}

The initial stage is to find the mass composition concept that it wants to express in the research. The following explanation is how the concept of mass composition presents elementary school children in the building, following the previously discussed theory, namely the Heidegger theory of dasein. a) Characteristics of Children's
Drawing

This research wants to present the existence of children through the concept of mass composition, which is taken from the paintings of elementary school children. Paintings are chosen based on human existence that began when they entered elementary school education. At this stage, children pour their thoughts or existence through a painting before they can finally write (Binkley, 1988). According to Misty Adinou, a professor in language and literacy at the University of Canberra, children like to draw flower objects because of their simple shapes, and they're 
easy to paint (Adoniou, 2016). Therefore, the mass composition design stage is a flower painting from a sketch of elementary school children.
The characteristics of a flower painting of elementary school children can be seen in Figure 4. These characteristics are translated into mass compositions using the intangible metaphor architectural approach.

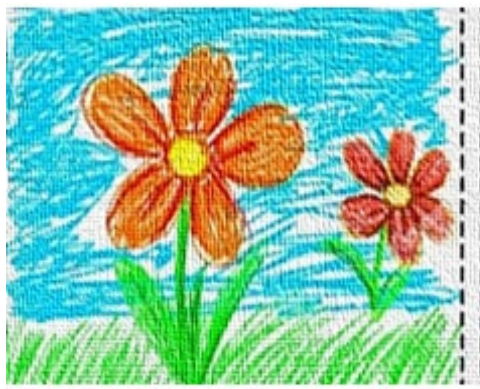

(a)

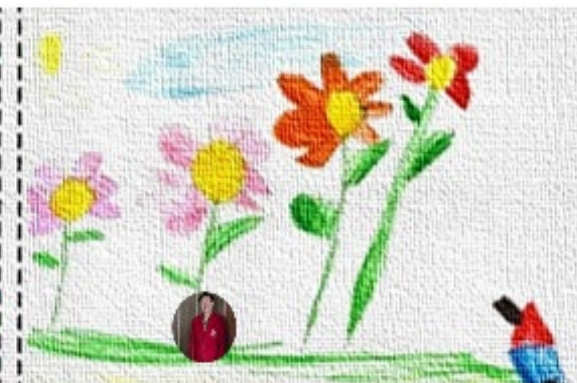

(b)

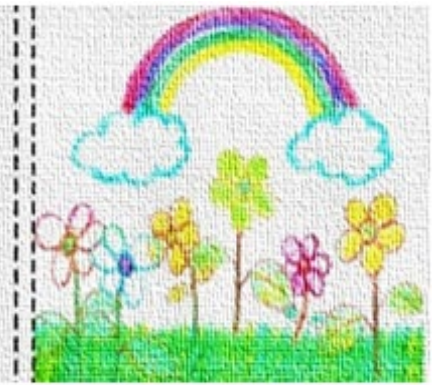

(c)

Figure 4 : Flower Painting by Elementary School Children.

b) Translated Using Metaphorical Architecture

From the description of the characteristics of flower painting in elementary school children, it is found that the concept of mass is taken from the sketch of flowers in general. This sketch has a mass of flower petals that are of different scales so that it can be seen that children can disproportionately express the flower drawing sketch. Then, the mass of this building consists of two adjoining masses of flowers, with a connector as the connection. In this mass, skylights were created at several points to include sunlight which depicts how the children draw the details of the sun in their paintings (Figure 5).

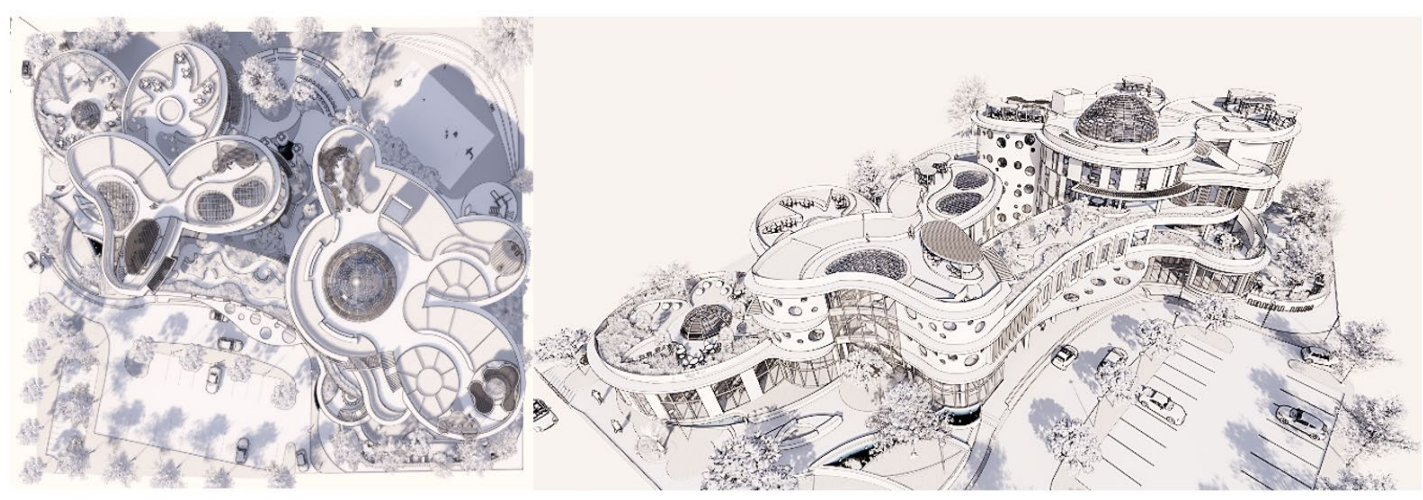

Figure 5 : Mass Compositions with Metaphorical Concepts from Elementary School Children’s Flower Paintings.

Source: Authors, 2021

\subsection{Creative Spaces}

After designing a mass composition, the next step is to create a creative space concept in the building. This research uses a tool in the form of a pattern language from Thoring's (2019) pattern language of creative spaces. This section explains what kind of spatial typology researchers want to create in research, which patterns can be used to create this typology, and finally, how to apply pattern language to research. a) Typology of Creative Spaces

Before applying creative space patterns in this research, it is necessary to know what creative space it wants to create so that the applied patterns can meet the creativity needs that occur in space. This typology of creative space identifies types of creative space that can accommodate certain creative activities and identify the quality of space created in research to support creative space. The following is to be described in Table 2 of the typology of creative space required in the main room program based on the type of creative space. 
Table 2 : Space Type to be Created in The Main Space Program.

\begin{tabular}{lccccccccc}
\hline $\begin{array}{c}\text { Space } \\
\text { Program/ } \\
\begin{array}{c}\text { Spatial } \\
\text { Quality }\end{array}\end{array}$ & $\begin{array}{c}\text { Multi } \\
\text { Hall }\end{array}$ & Cafetaria & Library & $\begin{array}{c}\text { Work- } \\
\text { shop }\end{array}$ & $\begin{array}{c}\text { Project } \\
\text { Display }\end{array}$ & $\begin{array}{c}\text { Art } \\
\text { Studio }\end{array}$ & $\begin{array}{c}\text { Common } \\
\text { Area }\end{array}$ & $\begin{array}{c}\text { STE } \\
\text { AM } \\
\text { Class } \\
\text { room }\end{array}$ & $\begin{array}{c}\text { Makers } \\
\text { Space }\end{array}$ \\
\hline $\begin{array}{l}\text { Personal } \\
\text { Space }\end{array}$ & & & & & & & $\bullet$ & & \\
\hline $\begin{array}{l}\text { Collaboration } \\
\text { Space }\end{array}$ & $\bullet$ & $\bullet$ & $\bullet$ & $\bullet$ & & $\bullet$ & $\bullet$ & $\bullet$ & $\bullet$ \\
\hline $\begin{array}{l}\text { Presentation } \\
\text { Space }\end{array}$ & & & $\bullet$ & $\bullet$ & $\bullet$ & $\bullet$ & & $\bullet$ & $\bullet$ \\
\hline $\begin{array}{l}\text { Making } \\
\text { Space }\end{array}$ & & & $\bullet$ & $\bullet$ & & $\bullet$ & & $\bullet$ & $\bullet$ \\
\hline $\begin{array}{l}\text { Intermission } \\
\text { Space }\end{array}$ & $\bullet$ & $\bullet$ & $\bullet$ & & $\bullet$ & $\bullet$ & $\bullet$ & $\bullet$ & $\bullet$ \\
\hline
\end{tabular}

Source: Authors, 2021

In addition, the typology of creative space required in the main room program also is explained based on the quality of the creative space created in Table 3 below.

Table 3 : Spatial Quality to be Realized in The Main Space Program.

\begin{tabular}{|c|c|c|c|c|c|c|c|c|c|}
\hline $\begin{array}{c}\text { Space } \\
\text { Program/ } \\
\text { Spatial } \\
\text { Quality } \\
\end{array}$ & $\begin{array}{c}\text { Multi } \\
\text { Hall }\end{array}$ & Cafetaria & Library & $\begin{array}{l}\text { Work- } \\
\text { shop }\end{array}$ & $\begin{array}{l}\text { Project } \\
\text { Display }\end{array}$ & $\begin{array}{c}\text { Art } \\
\text { Studio }\end{array}$ & $\begin{array}{c}\text { Common } \\
\text { Area }\end{array}$ & $\begin{array}{c}\text { STE } \\
\text { AM } \\
\text { Class } \\
\text { room } \\
\end{array}$ & $\begin{array}{c}\text { Makers } \\
\text { Space }\end{array}$ \\
\hline $\begin{array}{l}\text { Knowledge } \\
\text { Processor }\end{array}$ & & & 0 & 0 & 0 & 0 & & $\vartheta$ & $\bullet$ \\
\hline $\begin{array}{l}\text { Indicator of } \\
\text { Culture }\end{array}$ & & & $\bullet$ & & & & $\bullet$ & & $\bullet$ \\
\hline $\begin{array}{l}\text { Process } \\
\text { Enabler }\end{array}$ & $\bullet$ & & & & & $\bullet$ & & & $\bullet$ \\
\hline $\begin{array}{l}\text { Social } \\
\text { Dimension }\end{array}$ & & 0 & $\bullet$ & & & & $\bullet$ & & $\bullet$ \\
\hline $\begin{array}{l}\text { Source of } \\
\text { Stimulation }\end{array}$ & $\bullet$ & $\bullet$ & $\bullet$ & $\bullet$ & $\bullet$ & $\bullet$ & $\bullet$ & $\bullet$ & $\bullet$ \\
\hline
\end{tabular}

After knowing the typology of creative space it want to create, it can be seen what creative space patterns need to be applied in this research to realize the desired typology of creative space by number (Thoring, 2019). The patterns chosen to create the desired creative space typology in research based on the spatial type and spatial quality are as follows in Tables 4 and 5 .

Table 4 : Selected Patterns That Will be Applied to Create Space Type according to Thoring (2019), elaborated by Authors, 2021.

\begin{tabular}{|c|c|}
\hline Space Type & Pattern \\
\hline Personal Space & (19) The Capsule; (34) Empty Space; (37) View Variation. \\
\hline $\begin{array}{l}\text { Collaboration } \\
\text { Space }\end{array}$ & $\begin{array}{l}\text { (5) Writable Surface; (8) High Seat; (22) Cabinet of Curiosities; (23) Playground; (25) } \\
\text { The Flexroom; (34) Empty Space; (36) Semi-Privacy; (37) View Variation; (39) } \\
\text { Vertical Distance; (40) Asymetric Floorplan. }\end{array}$ \\
\hline Presentation Space & (13) Showcase; (34) Empty Space; (37) View Variation. \\
\hline Making Space & $\begin{array}{l}\text { (22) Cabinet of Curiosities; (34) Empty Space; (37) View Variation; (39) Vertical } \\
\text { Distance. }\end{array}$ \\
\hline Intermission Space & $\begin{array}{l}\text { (6) The Green-House; (11) The Bean-bag; (12) Communal Table; (13) Showcase; (19) } \\
\text { The Capsule; (23) Playground; (24) The Anchor; (33) Leftover Space; (34) Empty } \\
\text { Space; (39) Vertical Distance; (42) The Reception; (45) Outer Spaces. }\end{array}$ \\
\hline
\end{tabular}


Table 5 : Selected Patterns That Will be Applied to Create Spatial Quality according to Thoring (2019), elaborated by Authors, 2021.

\begin{tabular}{ll}
\hline \multicolumn{1}{c}{ Spatial Quality } & \multicolumn{1}{c}{ Pattern } \\
\hline $\begin{array}{l}\text { Knowledge } \\
\text { Processor }\end{array}$ & $\mathbf{( 5 )}$ Writable Surface; (13) Showcase; (22) Cabinet of Curiosities. \\
\hline Indicator of Culture & $\mathbf{( 1 1 )}$ The Bean-bag. \\
\hline Process Enabler & $\mathbf{( 5 )}$ Writable Surface; (8) High Seat; (25) The Flex room; (34) Empty Space. \\
\hline Social Dimension & $\begin{array}{l}\text { (12) Communal Table; (19) The Capsule; (24) The Anchor; (36) Semi-Privacy; (42) } \\
\text { The Reception. }\end{array}$ \\
\hline $\begin{array}{l}\text { Source of } \\
\text { Stimulation }\end{array}$ & $\begin{array}{l}\text { (6) The Green-House; (11) The Bean-bag; (13) Showcase; (19) The Capsule; (22) } \\
\text { Cabinet of Curiosities; }(\mathbf{2 3}) \text { Playground; (33) Leftover Space; (34) Empty Space; (36) } \\
\text { Semi-Privacy; }(\mathbf{4 0}) \text { Asymetric Floorplan; (45) Outer Space. }\end{array}$ \\
\hline
\end{tabular}

b) Pattern Language of Creative Spaces

There are 19 building patterns; the pattern placement has been adjusted to the spatial typology that the researcher wants to create in a particular space. To clarify, can see a pattern of creativity in the table below:

Table 6: Placement of Creative Space Patterns in the Main Room Program According to Thoring (2019), elaborated by Authors, 2021.

\begin{tabular}{|c|c|c|c|c|c|c|c|c|c|}
\hline $\begin{array}{c}\text { Pattern/ } \\
\text { Space }\end{array}$ & $\begin{array}{c}\text { Multi } \\
\text { Hall }\end{array}$ & Cafétaria & Library & $\begin{array}{l}\text { Work- } \\
\text { shop }\end{array}$ & $\begin{array}{l}\text { Project } \\
\text { Display }\end{array}$ & $\begin{array}{c}\text { Art } \\
\text { Studio }\end{array}$ & $\begin{array}{l}\text { Common } \\
\text { Area }\end{array}$ & $\begin{array}{c}\text { STEAM } \\
\text { Classroom }\end{array}$ & $\begin{array}{c}\text { Makers } \\
\text { Space }\end{array}$ \\
\hline $\begin{array}{l}\text { No. } 5 \\
\text { Writable } \\
\text { Surfaces }\end{array}$ & & & & & & 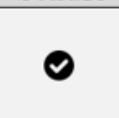 & & & $\bullet$ \\
\hline $\begin{array}{l}\text { No. } 6 \\
\text { The Green- } \\
\text { house }\end{array}$ & & & & & & & $\theta$ & & \\
\hline $\begin{array}{l}\text { No. } 8 \\
\text { High Seat }\end{array}$ & & & & & & & & & $\bullet$ \\
\hline $\begin{array}{l}\text { No. 11 } \\
\text { The } \\
\text { Beanbag }\end{array}$ & & & $\bullet$ & & & & $\theta$ & & 0 \\
\hline $\begin{array}{l}\text { No. } 12 \\
\text { The } \\
\text { Communal } \\
\text { Table }\end{array}$ & & & $\bullet$ & & & & 0 & & \\
\hline $\begin{array}{l}\text { No. 13 } \\
\text { Showcase }\end{array}$ & & & & 0 & $\bullet$ & $\bullet$ & & 0 & 0 \\
\hline $\begin{array}{l}\text { No. } 19 \\
\text { The Capsule }\end{array}$ & & & & & & & $\bullet$ & & \\
\hline $\begin{array}{l}\text { No. } 22 \\
\text { Cabinet of } \\
\text { Curiosities }\end{array}$ & & & $\bullet$ & $\bullet$ & & 0 & & $\bullet$ & $\bullet$ \\
\hline $\begin{array}{l}\text { No. } \mathbf{2 4} \\
\text { The Anchor }\end{array}$ & & $\bullet$ & $\bullet$ & & $\bullet$ & & $\bullet$ & & \\
\hline $\begin{array}{l}\text { No. 25 } \\
\text { The Flex } \\
\text { Room }\end{array}$ & $\bullet$ & & & & & & & & \\
\hline $\begin{array}{l}\text { No. 33 } \\
\text { Leftover } \\
\text { Space }\end{array}$ & & & & & 0 & & $\bullet$ & & \\
\hline
\end{tabular}

47 Journal of Design and Built Environment, Vol 21(2) 39-58, August $2021 \quad$ Trisno. et al. 


\begin{tabular}{|c|c|c|c|c|c|c|c|c|c|}
\hline $\begin{array}{l}\text { Pattern/ } \\
\text { Space }\end{array}$ & $\begin{array}{c}\text { Multi } \\
\text { Hall }\end{array}$ & Cafétaria & Library & $\begin{array}{l}\text { Work- } \\
\text { shop }\end{array}$ & $\begin{array}{l}\text { Project } \\
\text { Display }\end{array}$ & $\begin{array}{c}\text { Art } \\
\text { Studio }\end{array}$ & $\begin{array}{c}\text { Common } \\
\text { Area }\end{array}$ & $\begin{array}{l}\text { STEAM } \\
\text { Classroom }\end{array}$ & $\begin{array}{c}\text { Makers } \\
\text { Space }\end{array}$ \\
\hline \multicolumn{10}{|l|}{ No. 34} \\
\hline $\begin{array}{l}\text { Empty } \\
\text { Space }\end{array}$ & & & & 0 & & 0 & & & 0 \\
\hline \multirow{2}{*}{\multicolumn{10}{|c|}{$\begin{array}{l}\text { No. } 35 \\
\text { Informal }\end{array}$}} \\
\hline & & & & & & & & & \\
\hline Library & & & $\bullet$ & & & & & & \\
\hline \multirow{2}{*}{\multicolumn{10}{|c|}{ No. 36}} \\
\hline Semi- & & & & & & & & & \\
\hline Privacy & & & $\bullet$ & $\bullet$ & & & $\bullet$ & $\bullet$ & 0 \\
\hline \multicolumn{10}{|l|}{ No. 37} \\
\hline View & & & $\bullet$ & 0 & $\bullet$ & $\bullet$ & 0 & 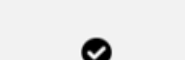 & \\
\hline Variations & 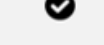 & & 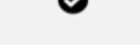 & 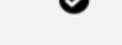 & $\sigma$ & $\sigma$ & $\sigma$ & 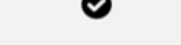 & $\bullet$ \\
\hline \multicolumn{10}{|l|}{ No. 39} \\
\hline Vertical & & & 0 & & & $\bullet$ & & & \\
\hline Distance & & & & & & & & & \\
\hline \multicolumn{10}{|l|}{ No. 40} \\
\hline $\begin{array}{l}\text { Asymmetric } \\
\text { Floorplan }\end{array}$ & $\bullet$ & $\bullet$ & $\bullet$ & $\bullet$ & & $\bullet$ & $\bullet$ & $\bullet$ & $\bullet$ \\
\hline \multicolumn{10}{|l|}{ No. 45} \\
\hline $\begin{array}{l}\text { Outer } \\
\text { Spaces }\end{array}$ & $\bullet$ & $\bullet$ & & & & & $\bullet$ & & \\
\hline
\end{tabular}

The selected patterns applied to research on various scales started from creating spatial functions, spatial forms, space placement, and spatial elements to furniture in space. In this section, the researcher describes; what patterns are applied, how to implement them, explanations and illustrations

Table 7: Application of Creative Spaces in Research.

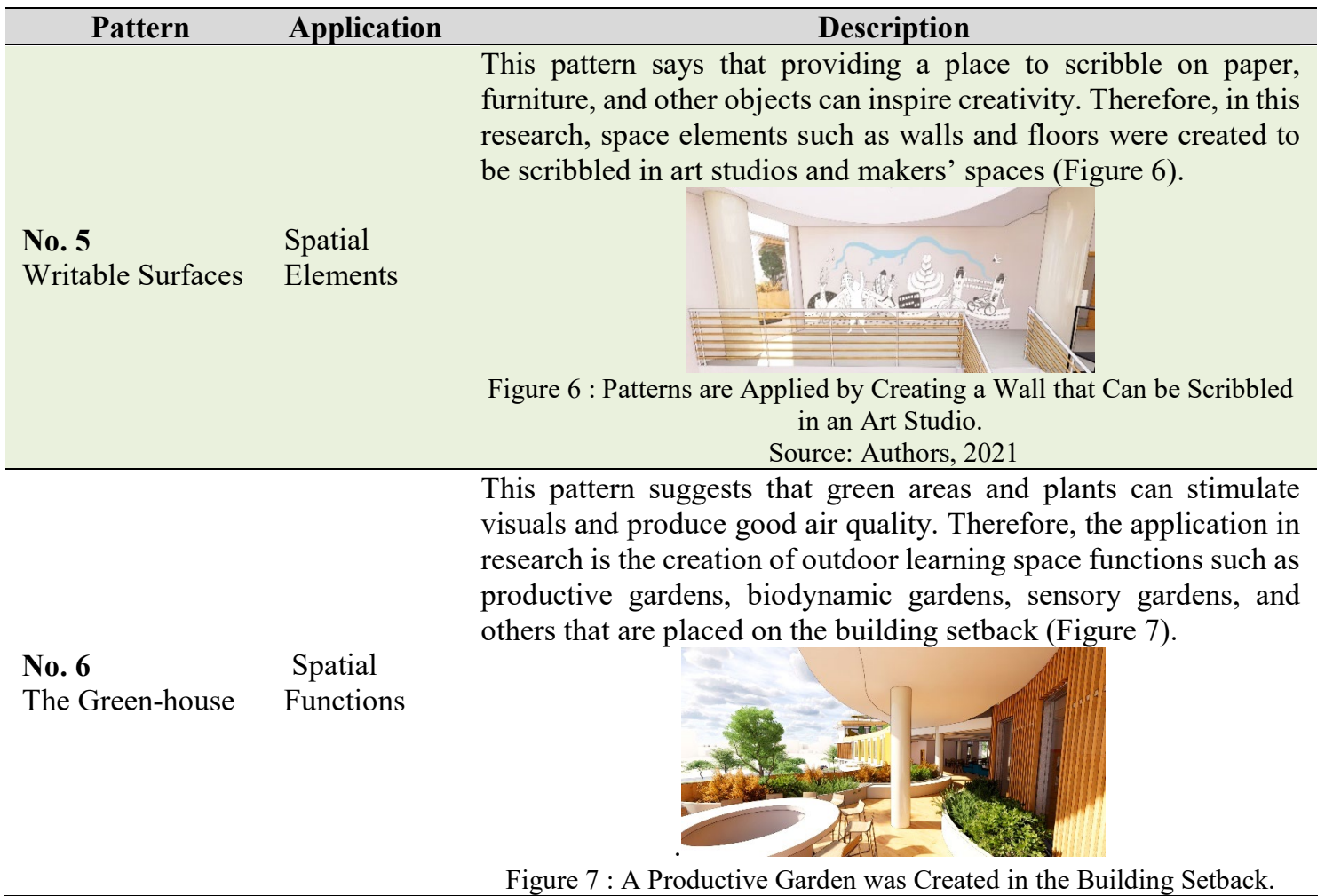




\begin{tabular}{|c|c|c|}
\hline Pattern & Application & Description \\
\hline & & Source: Authors, 2021 \\
\hline \multirow{3}{*}{$\begin{array}{l}\text { No. } 8 \\
\text { High Seat }\end{array}$} & \multirow{3}{*}{ Furniture } & $\begin{array}{l}\text { This pattern suggests that a tall chair provides better quality vision } \\
\text { and encourages participation in group work. Therefore, high chairs } \\
\text { were placed in the classroom, especially the makers' space, to } \\
\text { support the team's research-making activities (Figure 8). }\end{array}$ \\
\hline & & \\
\hline & & $\begin{array}{c}\text { Figure } 8 \text { : High Chairs in the Maker's Space Area. } \\
\text { Source: Authors, } 2021\end{array}$ \\
\hline
\end{tabular}

This pattern says that an unusual seat can invite the researcher to take a break and give a pleasant impression. Therefore, this pattern is applied by placing beanbag chairs in several spaces, such as the common area, game room, lobby, and makers space. Beanbags are also placed in outdoor areas such as outdoor reading areas and productive gardens (Figure 9).

No. 11

The Beanbag
Furniture

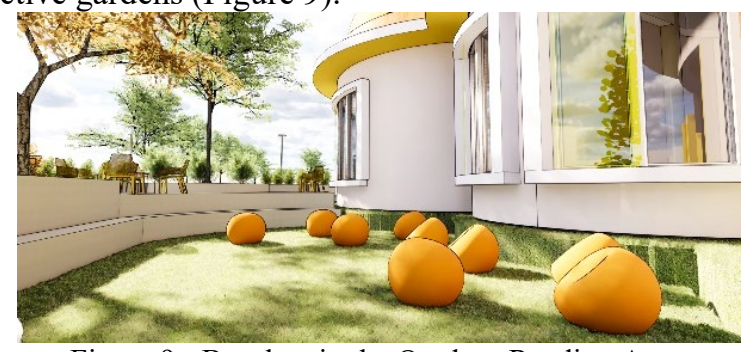

Figure 9 : Beanbag in the Outdoor Reading Area Source: Authors, 2021

This pattern suggests that shared tables placed in communal areas
encourage collaboration. Therefore, this research is applied by
placing communal tables in common areas such as learning
ordinary and everyday art (Figure 10).

No. 12

The Communal Furniture Table

\section{No. 13}

Showcase
Spatial function, Furniture

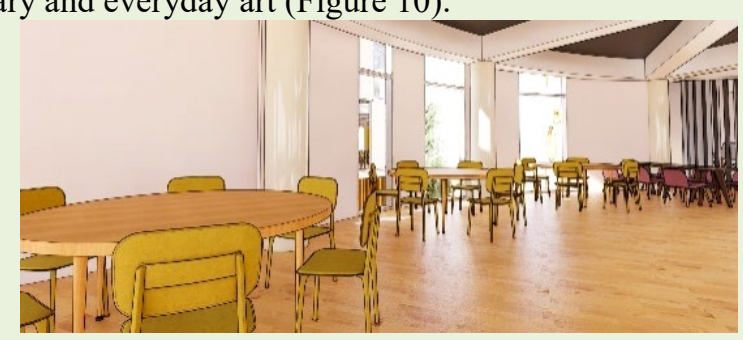

Figure 10 : Communal Table to Used Together in Learning Common. Source: Authors, 2021

This pattern says that a space that provides an area for inspiration, such as books and models, can inspire creativity. Therefore, the application in this research is creating a display project space that displays children's works to be an inspiration. This pattern is also applied to classrooms by displaying their work in specific areas by holding furniture on a project table (Figure 11).

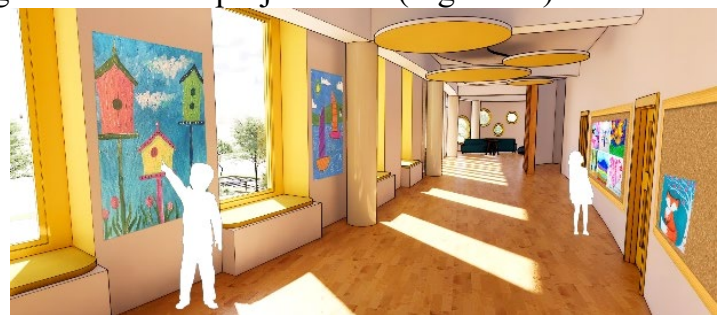

Figure 11 : Project Display to Display Children's Work. Source: Authors, 2021 


\begin{tabular}{lll}
\hline \multicolumn{1}{c}{ Pattern } & Application & Description \\
\hline & $\begin{array}{l}\text { This pattern says that the booth allows one to focus more on } \\
\text { thinking and to reflect. Therefore, this research, applied by creating } \\
\text { learning pods space in learning common areas (Figure 12). }\end{array}$ \\
$\begin{array}{ll}\text { No. } 19 \\
\text { The Capsule }\end{array}$ & Sunction & \\
&
\end{tabular}

This pattern says providing collections such as materials or even toys and technology can make someone think more creatively. Therefore, this pattern is applied to research by providing storage cabinets for prototyping tools and technology such as computers and $3 \mathrm{D}$ printing in classrooms, creating room functions such as visualization studios to support children's creative activities

No. 22

Cabinet of

Curiosities

Furniture

No. 23

Playground

Spatial

Function (Figure 13).

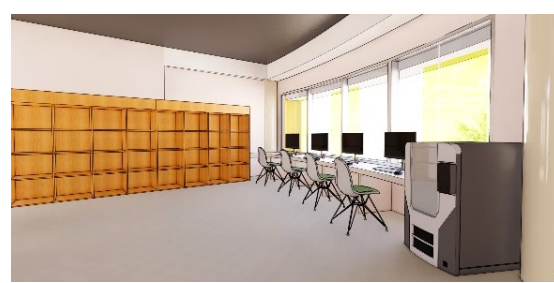

Figure 13 : Provision of Storage Cabinets, Computers \& 3D Printing for Makers Space.

Source: Authors, 2021

This pattern says that a room containing games, music, or sports facilities encourages experimentation and activities. Therefore, indoor spaces such as a Game room, Art Studio, Gymnasium, and outdoor such as a playground, sports field, water play area, and others were created (Figure 14).

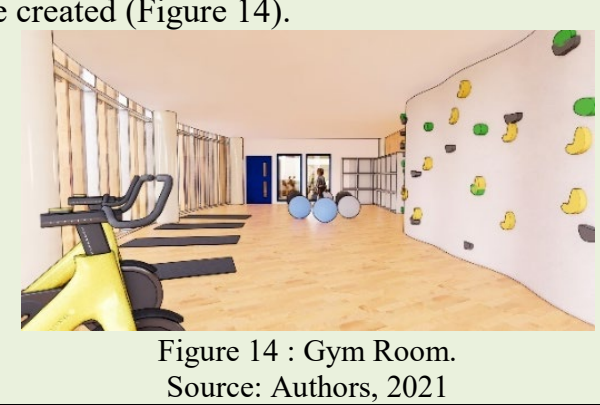

This pattern says that creating a central area where people meet between floors, fields, and buildings can generate creativity. Therefore, in researching spaces such as cafeterias, common areas (learning and typical art), libraries, project displays are used as areas where children of all class levels can meet and exchange ideas (Figure 15).

Spatial

No. 24

function,

The Anchor

Space

Placement

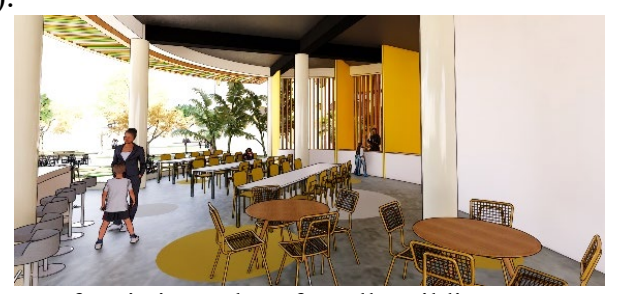

Figure 15 : Cafetaria is A Place for All Building Users to Meet and Exchange Ideas.

Source: Authors, 2021 


\begin{tabular}{lll}
\hline \multicolumn{1}{c|}{ Pattern } & Application & Description \\
\hline & & $\begin{array}{l}\text { This pattern says that providing space for various events is needed } \\
\text { to create creative space. Therefore, this pattern is applied to } \\
\text { research by creating a multi-hall that functions as a multipurpose } \\
\text { room directly to the surrounding community (Figure 16). }\end{array}$ \\
$\begin{array}{ll}\text { No. } \mathbf{2 5} \\
\text { The Flex room }\end{array}$ & $\begin{array}{l}\text { Spatial } \\
\text { Function }\end{array}$
\end{tabular}

This pattern says that the remaining spaces can invite ideas if they are reactivated. Therefore, this pattern is applied to research by activating school corridors, where corridors that are only used as places for students to move from one class to another are reactivated by making the area a common area and a display project, namely by providing places where all children can. Meet each other and exchange ideas by holding other facilities (Figure

$\begin{array}{ll}\text { No. 33 } & \text { Spatial } \\ \text { Leftover Space } & \text { Function }\end{array}$ 17).

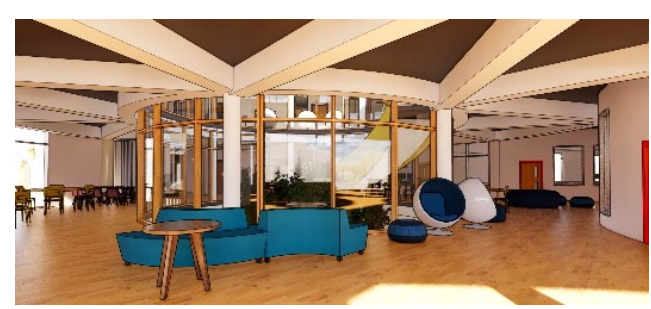

Figure 17 : School Corridors that are Used as Learning Common. Source: Authors, 2021

This pattern says that white and empty space allows someone to imagine their ideas. Therefore, this pattern is applied to research using simple materials and colors such as white and wooden floors in classrooms, such as makers space, art studios, and workshops (Figure 18).

$\begin{array}{ll}\text { No. } 34 & \text { Space } \\ \text { Empty Space } & \text { Element }\end{array}$

$\begin{array}{ll}\text { No. 36 } & \text { Space } \\ \text { Semi-Privacy } & \text { Element }\end{array}$

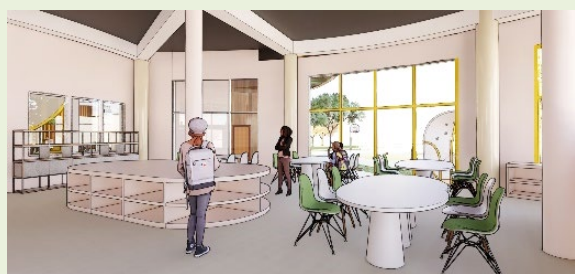

Figure 18: The Use of White Color in the Workshop Space. Source: Authors, 2021

This pattern says that creating a view between rooms allows one to observe what other people are doing and inspires inspiration. Therefore, this research is applied by creating a space with an element of space opening in the form of a large window that provides a visual connection that is not too open like a glass wall and does not cause noise (Figure 19).

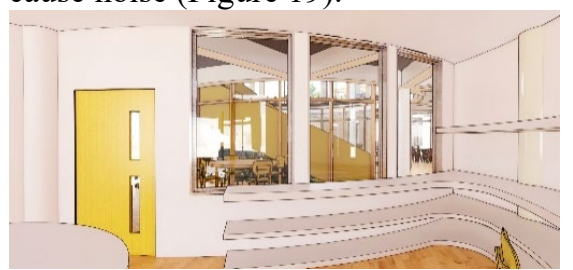

Figure 19 : Windows in The STEAM Classroom with Visual Access to Learning Common.

Source: Authors, 2021 


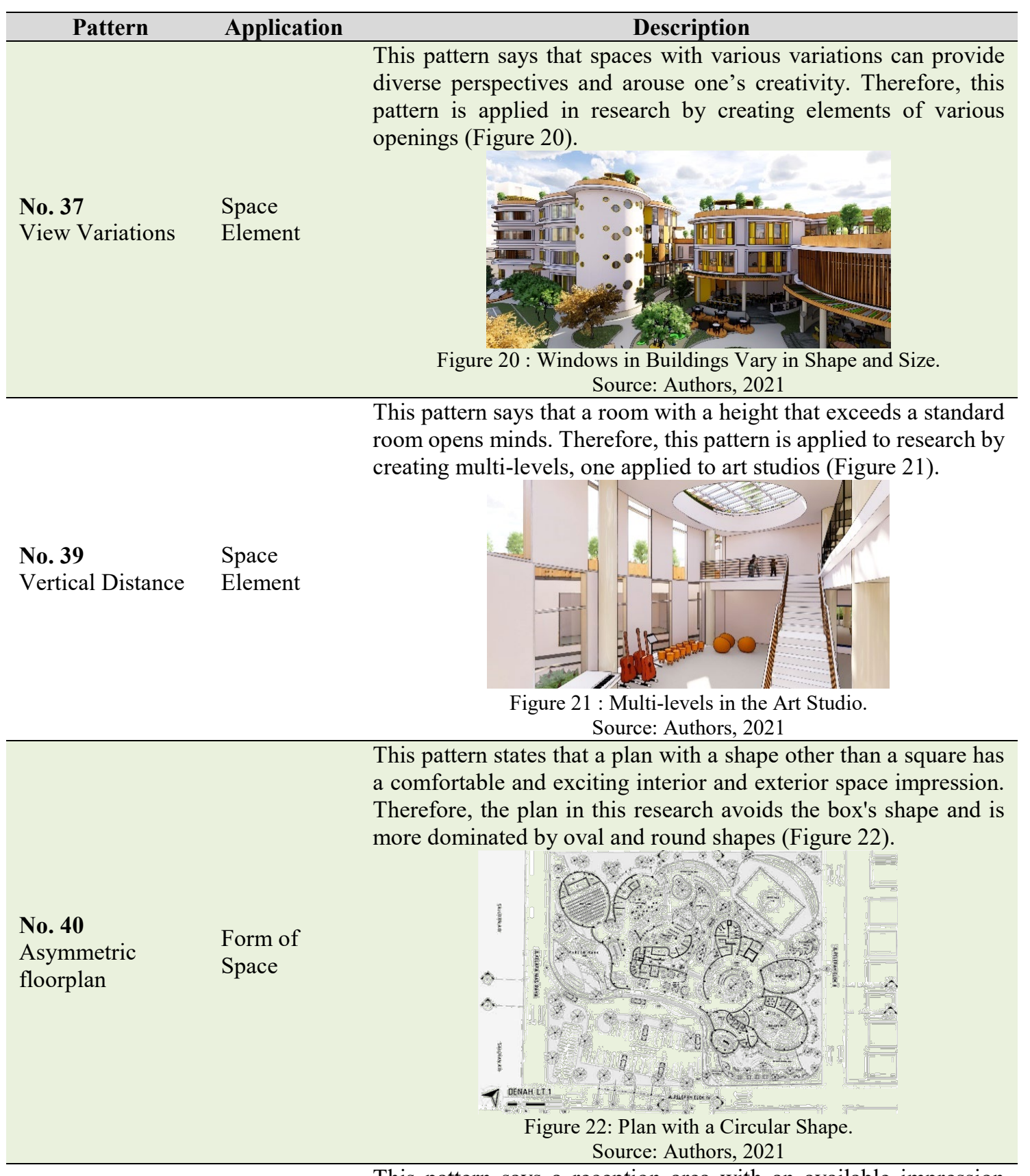

This pattern says a reception area with an available impression creates a positive climate that impacts the mood of building users and encourages them to be creative. Therefore, this pattern is applied to research by creating an open lobby area by eradicating space and the room's concept where the reception area is placed to welcome visitors. There is also a sitting area where people can discuss and exchange ideas (Figure 23).

$\begin{array}{ll}\text { No. } 42 & \text { Space } \\ \text { The Reception } & \text { Element }\end{array}$

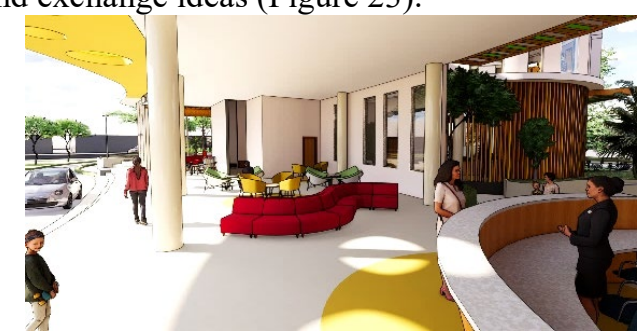

Figure 23 : Lobby Area.

Source: Authors, 2021

\begin{tabular}{lll} 
No. 45 & Space & This pattern says that spaces with access to outdoor areas give \\
Outer Spaces & Element & people the opportunity to take a break and produce new \\
\hline
\end{tabular}




Pattern \begin{tabular}{c} 
Description \\
\hline perspectives. Therefore, this pattern is applied to research by \\
creating a solid spatial relationship between indoor and outdoor, \\
where each common area in this research is connected to an \\
outdoor learning area. Also created an element that divides the \\
space without walls to create transparency between indoor and \\
outdoor areas (Figure 24).
\end{tabular}
Figure 24: Art Typical That is Directly Connected to the Productive
Garden.
Source: Authors, 2021

Source: Authors, 2021

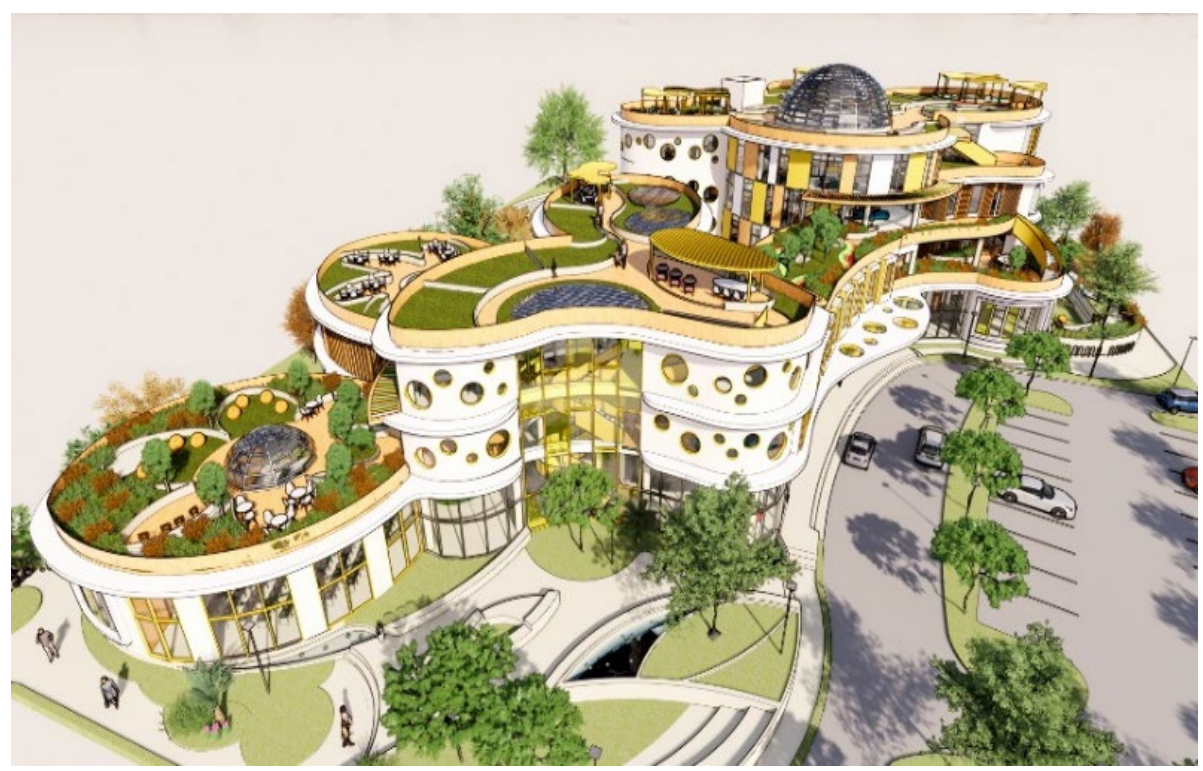

Figure 25: Exterior Perspective.

Source: Authors, 2021

From all stages of the method, the results obtained from this research are an elementary school building with a STEAM curriculum where the elements of creativity in the curriculum are created in architectural form without forgetting the human existence in them, namely children of elementary school age (Figure 25). The tools used to realize the element of creativity in research are to create creative spaces using the pattern language which is applied in various forms starting from the selection of furniture, the creation of spatial elements, the form of space, the placement of space to the creation of certain room functions.

The presence of children is also presented by metaphor. The painting is a tool for them to state their existence. Where flowers are used as objects to be presented in mass compositions, by taking the characteristics of flower painting in children to sublimate the metaphorical architecture, it is hoped that their presence can be present in the building. These two methods have an essential role in creating an elementary school building for the STEAM curriculum that is intact, efficient, and has its essence for its users. This research also shifted the school design in the 19th century, which only thought about functionality by thinking more about all the essential elements in a school, namely the curriculum that occurred and the humans in it, so that learning spaces could be created that could accommodate teaching and learning activities comfortably, accordingly and more fun.

\subsection{COVID-19 Prevention}

From the studies that have been conducted, several strategies can be carried out to prevent the occurrence of covid-19 transmission. The 
strategies applied in this research are as follows: a) Implementing the covid-19 protocol during the learning process at school; b) Implementing the Covid-19 design strategy.

\section{a) Covid-19 Protocol During School} Lessons

In addition to creating architectural design strategies, it is necessary to apply regulations to humans in buildings first so that the response to Covid-19 is effective and can be adequately realized. All building users must carry the regulations that applied to school buildings, starting from teachers, employees, students, parents, and others.

During the pandemic, the health protocols implemented to reduce the transmission of covid-19 are as follows: 1) Reduce classroom capacity to $50 \%$ less than usual to maximize social distancing, whereby $50 \%$ of children will be diverted to spaces that are rarely used, such as multihall, cafeteria, library, etc. for remote learning; 2) It is prohibited to congregate by keeping a distance between humans as far as 1.8 $\mathrm{m}$; 3) Clean hands every time you enter and leave the room so that the room is genuinely hygienic; 4) Check the temperature before entering the building to prevent any building user with covid-19 symptoms from entering the building and transmitting other building users; 5) Using online and offline learning systems so that all students can still obtain learning; 6) Use masks with medical standards to prevent airborne and droplet transmission; 7) Pay attention to cross ventilation and natural lighting; 8) Using a UVC lamp when there are no students by using a motion sensor and a timer to protect the skin and eyes (Figure 26) (Azanella \& Nugroho, 2020; Luzzatto-Fegiz, et al., 2021).

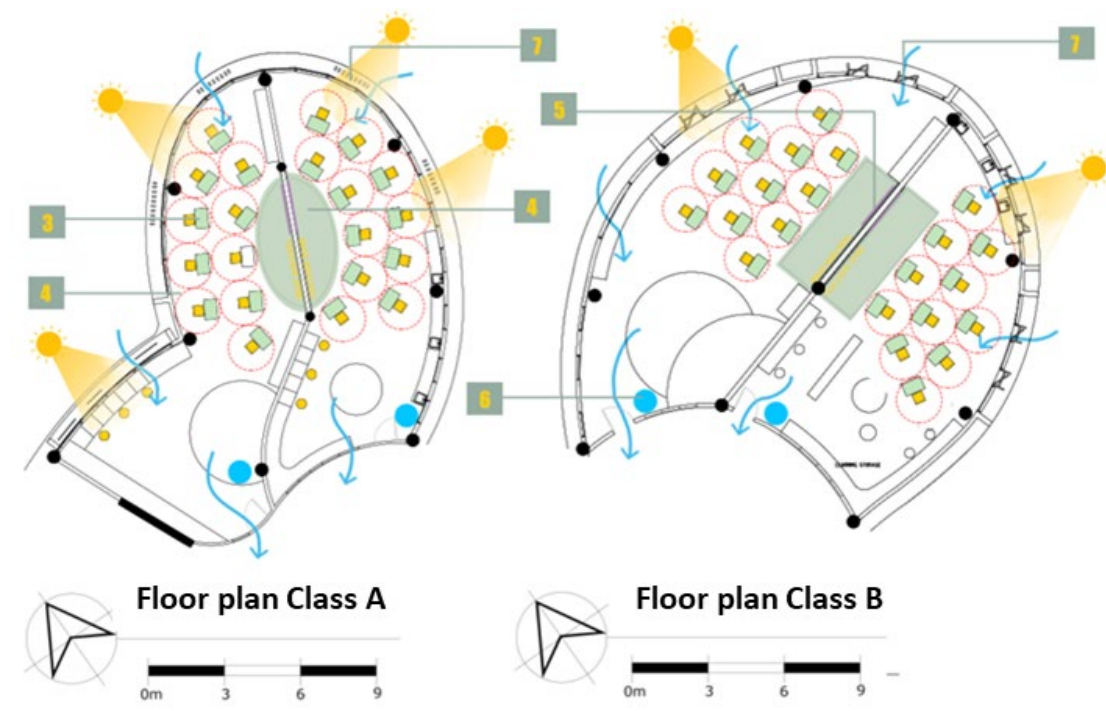

Figure 26: Covid-19 Design Strategies

Source: Authors, 2021

b) Covid-19 Strategy

The design indicators for the design strategy applied in this research are as follows:

- Openings to enter sunlight and air. Windows are created on two sides to create crossventilation while simultaneously introducing sunlight. Where according to AIA, one of the Covid-19 strategies is to include sunlight whenever possible.
- Set the table to face the same direction to reduce the chance of droplet transmission.

- 6 feet social distance tag to each table to pay attention to the spread of Covid-19.

- Implement technology such as shareware LED screens to facilitate remote learning in the classroom to monitor $50 \%$ of children learning from other rooms in the school.

- Use of UVC lamps when the room is not in use. 

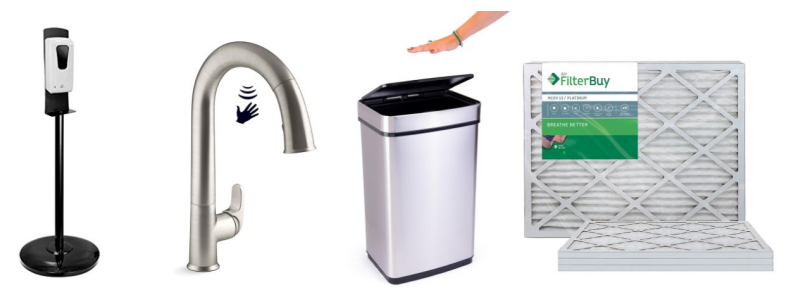

Figure 27: Technology adaptation to overcome covid-19.

It is adapting sanitation technology with touchless features such as touchless hand sanitizer, touchless sink, touchless trash bin, as shown in Figure 27, to be applied to research to maximize the prevention of Covid-19. These sanitary kits need to be placed in all rooms in the school. One of the most important elements of preventing
Covid-19 is creating a good air and lighting system, both natural and artificial. According to the American Society of Heating, Refrigerating and Air-Conditioning Engineers (ASHRAE), a homemade air system during a pandemic should replace the air filtration that usually uses the MERV-8 type MERV-13.

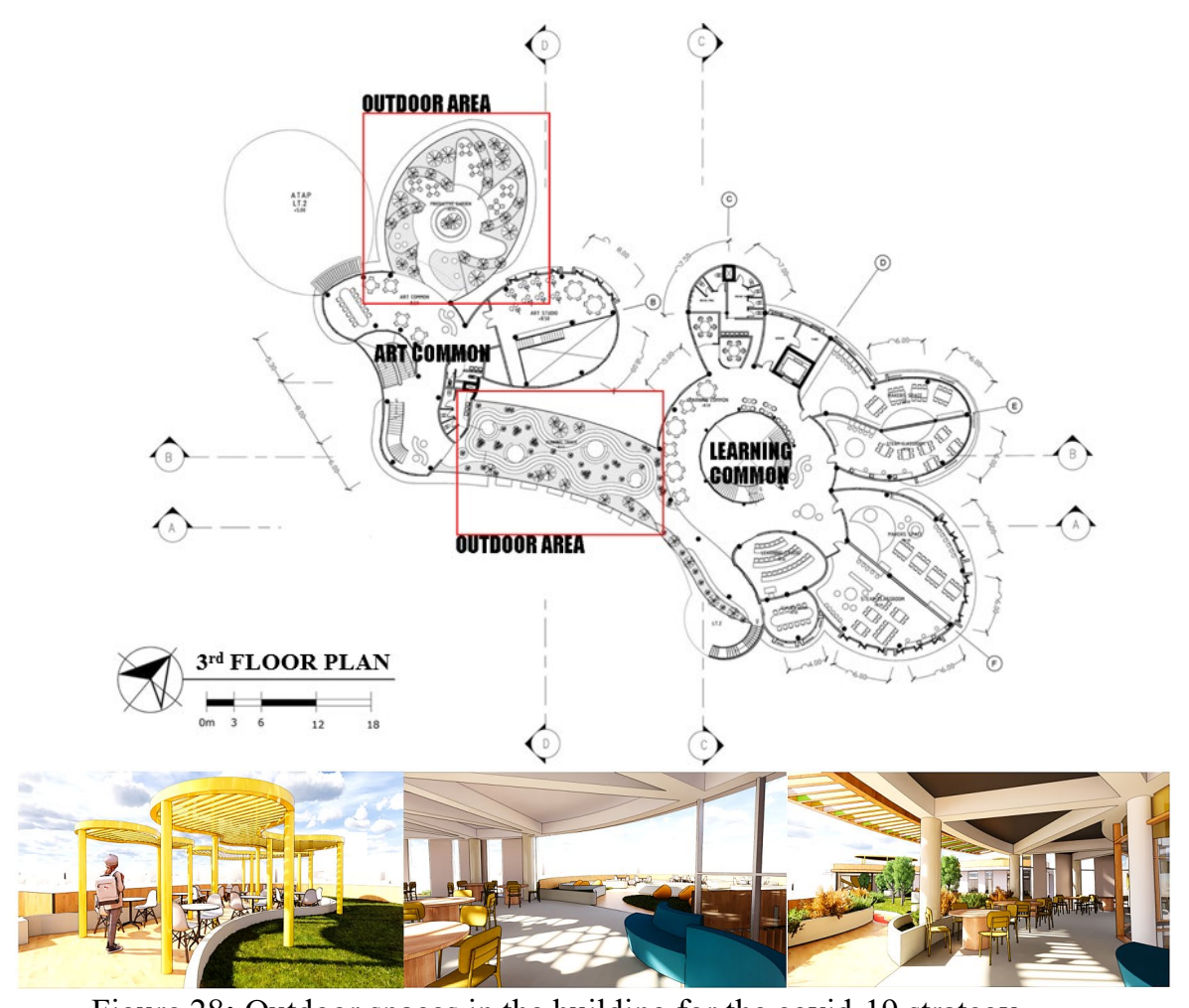

Figure 28: Outdoor spaces in the building for the covid-19 strategy.

Source: Authors, 2021

The creation of outdoor space in the research was also carried out to facilitate the natural flow of air into the building and a natural laboratory for children to learn. The room divider is also made without walls or massive to facilitate the free flow of air to enter the building and create good air in the building. This outdoor space was created to reduce the human capacity in the building, where to be comfortable to use it can be facilitated with temporary structures such as a canopy (Figure 28).

In the research itself, this outdoor space is placed in each common area to divert the density of the public area, which is a place usually used to gather and exchange ideas. According to Cassier and Meyer's views from Heidegger, green open space can open up activities to exchange ideas and socialize between humans (Trisno \& Lianto, 2018). In addition, this placement allows a strong relationship between all indoor and outdoor learning spaces.

\section{CONCLUSION}

This research departs from the problem of "unpreparedness of human resources" in dealing with technological developments in the future, which causes a blur of human existence in this world, where changes in the education system are needed. The covid-19 incident is considered in this research as a time context concerning human 
existence. At the same time, the learning space in schools changes due to this incident. Indonesia, which has been behind in its education, needs to change, especially in the curriculum and educational buildings still left behind in the 19th century. STEAM as a curriculum that suits future needs was selected as a curriculum applied to research. Thus, the methodology used answers the main issue that is sublimated into the conclusions and findings.

Meanwhile, the architecture of educational buildings takes one of the essential elements of STEAM, namely creativity, to be created in its architectural form by creating creative spaces. Before creating a creative space, this research takes Heidegger's view on dasein to present human existence. In this context, namely the existence of elementary school children, to be applied with the metaphorical architectural method as a starting point for sublimating the child's existence into a building inspired by the flower painting of an elementary school child in the creation of mass compositions.

After that, the creative space in this research was created through a tool, namely the language of patterns, amounting to 19 patterns and applied in various forms in various spaces. This pattern selection is based on the typology of creative space wanted to be created in this research. The final stage of this research is to think about the 'time' element of the Heidegger being and time philosophy by thinking about how the covid-19 design strategy is applied to this research through the creation of cross ventilation, designs to maximize social distancing, an adaptation of technology and the creation of outdoor spaces.

The findings of this research are; how to create a creative space to help the learning process in a school so that children can be motivated by their creativity, as an effort is to realize the existence of children in buildings, by referring to Heidegger's view of being and time in this research. So that it can answer the question; how we as an architect can present human presence in a building through architectural metaphors and how the Covid-19 design strategy can be applied to schools to continue teaching safely. The findings from this research are expected to be a design indicator for architects to create creative spaces in school educational buildings while still paying attention to the human presence in them safely from the Covid-19 pandemic.

\section{REFERENCES}

[1] Adoniou, M. (2016, September 1). The Conversation. Retrieved from What Can We Learn from Children's Drawings?: https://theconversation.com/what-can-welearn-from-childrens-drawings-64527

[2] Adriyawati, Utomo, E., Rahmawati, Y., \& Mardiah, A. (2020). STEAM-Project-Based Learning Integration to Improve Elementary School Students' Scientific Literacy on Alternative Energy Learning. Universal Journal of Educational Research, 8(5), 1863-1873. doi:10.13189/ujer.2020.080523

[3] Antoniades, A. C. (1992). Poetics of Architecture: Theory of Design. New York: Van Nostrand Reinhold.

[4] Asia News (2016) Cambodia Political Instability Hits Textile Sector: Down 30\%. Retrieved from http://www.asianews.it/newsen/Cambodia,-political-instability-hitstextile-sector:-down-30-38370.html

[5] Azanella, L. A., \& Nugroho, R. S. (2020, June 26). Benarkah Lampu UVC Bisa Membunuh Virus Corona? Simak Penjelasannya. Retrieved April 8, 2021, from Kompas.com: https://www.kompas.com/tren/read/2020/0 6/26/071500265/benarkah-lampu-uvc-bisamembunuh-virus-corona-simakpenjelasannya?page $=$ all

[6] Batey, M., \& Furnham, A. (2010). Creativity, Intelligence, and Personality: A Critical Review of the Scattered Literature. Genetic, Social, and General Psychology Monographs, 132(4), 355-429. doi:10.3200/MONO.132.4.355-430

[7] Binkley, M. R. (1988). Becoming a Nation of Readers: What Parents Can Do. California: Office of Educational Research and Improvement, U.S. Department of Education.

[8] Birt, J. R., \& Cowling, M. (2017). Toward Future 'Mixed Reality' Learning Spaces for STEAM Education. International Journal of Innovation in Science and Mathematics Education, 25(4), 1-16. Retrieved from https://openjournals.library.sydney.edu.au/i ndex.php/CAL/article/view/12173

[9] Bobenhausen, C., Grant, J., Lau, J., Leung, L., \& Scanlon, M. M. (2020). Reopening America: Strategies for Safer Buildings. COVID-19 Emerging Research and Public Health Data as of May 2020. The American Institute of Architects, 1-10. Retrieved from AIA:

https://content.aia.org/sites/default/files/20 20-

06/STN20_\%20PublicHealthBreifing_sm v01.pdf

[10] Caley, P., Philp, D. J., \& McCracken, K. (2008). Quantifying Social Distancing Arising from Pandemic Influenza. Journal of the Royal Society Interface, 5, 631-639. doi:10.1098/rsif.2007.1197 
[11] Corbuzer, D. (2020, August 18). Nadiem, What if a Generation Goes Stupid? Podcast, Nadiem Makarim - Deddy Corbuzier. (D. Corbuzer, Interviewer)

[12] Creator, T. C., \& Corona, E. (2020). Collection of Information Regarding COVID-19. Depok: Falkultas Kedokteran Universitas Indonesia.

[13] Davies, D., Snape, D. J., Collier, C., Digby, R., Hay, P., \& Howe, A. (2013). Creative learning environments in education - A systematic literature review. Thinking Skills and Creativity, 8, 80-91. doi:10.1016/j.tsc.2012.07.004

[14] DeJarnette, N. K. (2018). Implementing STEAM in the Early Childhood Classroom. European Journal of STEM Education, 3(3), 1-9. doi:10.20897/ejsteme/3878

[15] Dougherty, B. O., Minnich, B., Knight, M. D., Grandstaff-Rice, E., Sullivan, G., Kotob, J., . . . Scanlon, M. M. (2020). Reopening America: Strategies for Safer School. The American Institue of Architects, 1-16. Retrieved from https://content.aia.org/sites/default/files/20 20 -

08/Reopening_America_Strategies_for_S afer_Schools_June_2020_.pdf

[16] Ekawati, N. D., \& Marhaeni, A. (2019). Pengaruh Model Project Based Learning Berbasis 4C Terhadap Kemandirian Belajar dan Kemampuan Membaca Pemahaman pada Siswa Kelas IV SD Gugus III Kecamatan Kediri Kabupaten Tabanan. PENDASI: Jurnal Pendidikan Dasar Indonesia, 3(1), 41-51. doi:10.23887/jpdi.v3i1.2866

[17] Escombe, A. R., Oeser, C. C., Gilman, R. H., Navincopa, M., Ticona, E., Pan, W., . . . Evans, C. A. (2007). Natural Ventilation for the Prevention of Airborne Contagion. PLoS Medicine, $\quad 4(2), \quad 309-317$. doi:https://doi.org/10.1371/journal.pmed.00 40068

[18] Garcês, S., Pocinho, M., de Jesus, S. N., \& Viseu, J. N. (2016). The Impact of Creative Environment on the Creative Person, Process, and Product. Revista Avaliação Psicológica, 15(2), 169-176. doi:10.15689/ap.2016.1502.05

[19] Hau, N. H., Cuong, T. V., \& Tinh, T. T. (2020). Students and Teachers' Perspective of The Importance of Arts in Steam Education in Vietnam. Journal of Critical Reviews, 7(11), 666-671. doi:10.31838/jcr.07.11.121

[20] Heidegger, M. (2010). Being and Time. New York: State University of New York Press.

[21] IDN Times (2020) 6 Fakta Menarik Sistem Pendidikan Indonesia di Masa Kolonial Belanda. Retrived from https://www.idntimes.com/science/discover y/khusnul-khotimah-5/fakta-menariksistem-pendidikan-indonesia-masakolonial-belanda-exp-c1c2/3

[22] Iwuagwu, E. K. (2017). Martin Heidegger and The Question of Being. Journal of Integrative Humanism (JIH), 8(1), 25-48.

[23] Kesseiba, K. (2017). Introducing Creative Space: Architectural Design Studio for Architecture Students; Challenges and Aspirations. Journal of Advance in Social Science and Humanities, 3(8), 3622436237. doi:10.15520/jassh38240

[24] Kyung Jung, Y., \& Hong, H. (2020). A Theoretical Need for Applying Flipped Learning to STEAM Education. ResearchGate.

[25] Lavranos, C., Manousaki, C. V., \& Kostagiolas, P. (2020). Developing Creative "Spaces" in Libraries for Creative Tourism. Qualitative and Quantitative Methods in Libraries, 9(1), 1-7. Retrieved from http://www.qqml.net/index.php/qqml/articl e/view/534

[26] Levin, H. (2007). Natural Ventilation for Prevention of Airborne Contagion: Conclusions Overgeneralized. Plos Medicine, e189. doi:10.1371/journal.pmed.0040189

[27] Liputan 6 (2020) Puluhan Wali Murid di Surabaya Tolak PPDB Jalur Zonasi. Retreived from https://surabaya.liputan6.com/read/429498 8/puluhan-wali-murid-di-surabaya-tolakppdb-jalur-zonasi

[28] Luzzatto-Fegiz, P., Temprano-Coleto, F., Peaudecerf, F. J., Landel, J. R., Zhu, Y., \& McMurry, J. A. (2021). UVB Radiation Alone May Not Explain Sunlight Inactivation of SARS-CoV-2. The Journal of Infectious Diseases, 223(8), 1500-1502. doi:10.1093/infdis/jiab070

[29] Mustafa, F. A., \& Rafieq, D. A. (2019). Assessment of elementary school buildings in Erbil city using space syntax analysis and school teachers' feedback. Alexandria Engineering Journal, 58(3), 1039-1052. doi:10.1016/j.aej.2019.09.007

[30] Ohba, M., \& Lun, I. (2010). Overview of Natural Cross-Ventilation Studies and the Latest Simulation Design Tools Used in Building Ventilation-Related Research. Advances in Building Energy Research, 4(1), 127-166. doi:10.3763/aber.2009.0405

[31] Putra, I. P. (2020, November 10). The Quality of Education in Indonesia has Lagged Behind 128 years (Kualitas Pendidikan Indonesia Tertinggal 128 Tahun). Retrieved from Medcom.id: https://www.medcom.id/pendidikan/news- 
pendidikan/ybDVR0qK-kualitaspendidikan-indonesia-tertinggal-128-tahun

[32] Qian, H., Li, Y., Seto, W. H., Ching, P., Ching, W. H., \& Sun, H. Q. (2010). Natural Ventilation for Reducing Airborne Infection in Hospitals. Building and Environment, 45(3), 559-565. doi:10.1016/j.buildenv.2009.07.011

[33] STEAMedu (Director). (2015). STEAM Education Program Overview [Motion Picture]. Retrieved from https:/www.youtube.com/watch?v=0tkAv WWhKf4

[34] Tasci, B. G. (2015). Project Based Learning from Elementary School to College, Tool: Architecture. Procedia - Social and Behavioral Sciences, 186, 770-775. doi:10.1016/j.sbspro.2015.04.130

[35] Taylor, P. C. (2016). Why is a STEAM curriculum perspective crucial to. ACEReSearch.

[36] Thoring, K. (2019). Designing Creative Space: A Systemic View on Workspace Design and its Impact on the Creative Process. Delft: Delft University of Technology.

[37] Tjahyadi, S. (2008). Humans and Their Historicity According to Martin Heidegger. Jurnal Filsafat, 1, 47-58. Retrieved from https://media.neliti.com/media/publications /84925-ID-manusia-dan-historisitasnyamenurut-mart.pdf

[38] Trisno, R., \& Lianto, F. (2018). Realization of Hybrid Concept and Symbiosis in Green Open Space (RTH) at Housing Complex RW (Neighborhood Councils) Pluit, Jakarta Utara, Indonesia. Journal of Physics: Conference Series, 1-6. Retrieved from https://iopscience.iop.org/article/10.1088/1 742-6596/1179/1/012165/meta

[39] Trisno, R., \& Lianto, F. (2019). Relationship Between Function-Form in The Expression of Architectural Creation. Advance Preprint. doi:10.31124/advance.8275322
[40] Trisno, R., \& Lianto, F. (2021). Lao Tze and Confucius' Philosophies Influenced the Designs of Kisho Kurokawa and Tadao Ando. City, Territory, and Architecture, 8(1), 1-11. doi:10.1186/s40410-021-00138$\mathrm{x}$

[41] WHO, W. H. (2020). Water, Sanitation, Hygiene, and Waste Management for SARSCoV-2, the Virus that Cause Covid-19. Retrieved from https://apps.who.int/iris/rest/bitstreams/129 2822/retrieve

[42] Wicaksono, S. R. (2020). Joyful Learning in Elementary School. International Journal of Theory and Application in Elementary and Secondary School Education, 2(2), 80-90. doi:10.31098/ijtaese.v2i2.232

[43] Yakman, G. '. (2008). STEAM Education: An Overview of Creating a Model of Integrative Education.STE@M Educational Model, 335-358. Retrieved from https://www.iteea.org/File.aspx?id=86752 $\& v=75 a b 076 a$

[44] Yang, J., Nam, I., Yun, H., Kim, J., Oh, H.j., Lee, D., . . . Sohn, J.-R. (2015). Characteristics of Indoor Air Quality at Urban Elementary Schools in Seoul, Korea: Assessment of Effect of Surrounding Enviroments. Atmospheric Pollution Research, 6(6), 1113-1122. doi:10.1016/j.apr.2015.06.009

[45] Zubaidah, S. (2018). Get to Know 4C: Learning and Innovation Skills to Face The Era of Industrial Revolution 4.0 (Mengenal 4C: Learning and Innovation Skills untuk Menghadapi Era Revolusi Industri 4.0). 2nd Science Education National Conference. Madura: Universitas Trunojoyo Madura. 